\title{
YAM BEAN VELVA DRAGON PRODUCTS BASED ON RED DRAGON FRUIT AND BENGKUANG AS AN ALTERNATIVE OF SNACK WITH INULIN AND ANTOSIANIN FIBER SOURCES
}

\author{
Nurjanah, Nia Fatimah ${ }^{1}$; Fauziyah, Roro Nur ${ }^{1}$; Rosmana, Dadang ${ }^{1}$ \\ ${ }^{1}$ Poltekes Kemenkes Bandung
}

\begin{abstract}
No infectious disease (PTM) has become a health problem for every country. One of the main cause of PTM is food control by consuming foods that contain Inulin (bengkuang tubers) and anthocyanins (dragon fruit). Intermittent food products consisting of velva become more effective because in one product already has a lot of special nutritional content of inulin and anthocyanin fibers. The design of this study was experimental with a completely randomized design (CRD). The research method uses hedonic tests, spectrophotometry for anthocyanin levels, and literature tests for inulin fiber levels. This study involved 30 panelists who were students of the Nutrition Department of the Poltekkes Bandung. This product formulation consists of three dragons and bengkuang, which is counterpart 1 (30\%: 70\%), counterpart 2 (70\%: 30\%), and counterpart 3 (50\%: $50 \%$ ). The hedonic test results showed that the level of preference consisted of counterpart two and the Kruskal-Wallis test results showed differences between the aspects of color, taste, and aroma with a value of $p<\alpha$ and also none in the design of the texture with $p>\alpha$. The level of anthocyanin product serving is $6.04 \mathrm{mg}$ and can fulfill $81 \%$ of the anthocyanin requirement by consuming two serving sizes. In contrast, the level of Inulin per serving amounted to $2.1 \mathrm{~g}$ and can meet the needs of Inulin at least a day from $350 \%$ snack.
\end{abstract}

\section{Key words: Anthocyanin, Bengkuang, Dragon fruit, Inulin, Velva}

\begin{abstract}
ABSTRAK
Penyakit tidak menular (PTM) telah menjadi permasalahan kesehatan bagi tiap negara. Salah satu kontributor utama terjadinya PTM adalah kontrol makanan, dengan mengonsumsi makanan yang mengandung inulin (umbi bengkuang) dan antosianin (buah naga). Produk makanan selingan berupa velva menjadi lebih efektif karena dalam satu produk sudah memiliki banyak kandungan zat gizi terutama serat inulin dan antosianin. Desain penelitian ini adalah eksperimental dengan Rancangan Acak Lengkap (RAL) Metode penelitian menggunakan uji hedonik, spektrofotometri untuk kadar antosianin, dan uji literature untuk kadar serat inulin. Penelitian ini melibatkan 30 orang panelis agak terlatih yang merupakan mahasiswa Jurusan Gizi Poltekkes Bandung. Formulasi produk ini terdiri dari tiga imbangan buah naga dan bengkuang, yaitu imbangan 1 (30\%:70\%), imbangan 2 (70\%:30\%), dan imbangan 3 (50\%:50\%). Hasil uji hedonik menunjukan bahwa tingkat kesukaan terdiri ada pada imbangan 2 dan hasil uji Kruskal-Wallis menunjukan adanya perbedaan bermakna pada aspek warna,rasa, dan aroma dengan nilai $p<\alpha$ serta tidak ada perbedaan pada tekstur dengan $\mathrm{p}>\alpha$. Kadar antosianin pertakaran saji produk sebesar 6,04 $\mathrm{mg}$ dan dapat memenuhi sebesar $81 \%$ dari kebutuhan antosianin dengan mengonsumsi dua takaran saji. Sedangkan kadar inulin per takaran saji sebanyak 2,1 g dan dapat memenuhi kebutuhan inulin minimal sehari dari selingan sebanyak $350 \%$.
\end{abstract}

Kata Kunci :Antosianin, Bengkuang, Buah naga, Inulin, Velva 


\section{INTRODUCTION}

Non-communicable diseases or degenerative diseases have become health problems for every country in the world. According to WHO, it is estimated that many countries have suffered billions of dollars in losses due to this degenerative disease; therefore, it needs concrete steps to overcome them. ${ }^{1} \quad$ Nowadays, degenerative diseases have become the biggest cause of death in the world. Nearly 17 million people die early each year due to degenerative diseases. In Indonesia, the epidemiology transition causes a shift in disease patterns, and chronic degenerative diseases have increased. Degenerative diseases are chronic noncommunicable diseases such as heart disease, hypertension, diabetes, and obesity.

The cardiovascular disease consists of various interrelated diseases such as atherosclerosis, hypertension, ischemic heart disease, peripheral vascular disease, and heart failure. These diseases are interrelated and often occur together. ${ }^{2}$ According to the 2013 Riskesdas, the prevalence of coronary heart disease based on a doctor's diagnosis in Indonesia was 0.5 percent and based on a doctor's diagnosis or symptoms of 1.5 percent. The prevalence of heart failure based on having been diagnosed by a doctor in Indonesia is 0.13 percent and based on a doctor's diagnosis or symptoms of 0.3 percent. The prevalence of hypertension in Indonesia based on the results of measurements at the age of $\geq 18$ years by 25.8 percent. So the coverage of health workers is only 36.8 percent; most $(63.2 \%)$ cases of hypertension in the community are undiagnosed. ${ }^{3}$ Another cause of degenerative diseases is Diabetes Mellitus (DM). DM is currently ranked fourth as a global epidemic that causes death.62 The prevalence of DM based on diagnosis or symptoms is 2.1 percent. ${ }^{3}$ Obesity is not only a problem of over nutrition but has been stated as a chronic disease that occurs in a long period. ${ }^{4,63}$ The prevalence of overweight in Indonesia is 13.5 percent, and obesity is 15.4 percent. ${ }^{3}$ One of the main contributors to the occurrence of degenerative diseases is unhealthy lifestyles such as smoking, drinking alcohol, eating patterns, and obesity, lack of physical activity, stress, and environmental pollution. ${ }^{1}$

One that can be controlled is diet. One diet is by consuming food sources of fiber food and food sources of antioxidants. According to Lattimer JM (2010) in Fairudz Alyssa. One of the things that can be done to prevent the terminal phase in degenerative diseases is by consuming foods that can reduce cholesterol levels, one of which is by consuming dietary fiber (dietary fiber) [5]. Meanwhile, according to Edgar David S et al. (2016) anthocyanin has two mechanisms in reducing total cholesterol levels, namely by inhibiting cholesteryl ester transfer protein (CETP) and inhibiting the enzyme HMG-CoA reductase. ${ }^{6}$

In general, dietary fiber has the potential to reduce cholesterol levels, one of which is by binding to fat in the small intestine, binding bile acids, and increasing its excretion to feces.[60] As a result, there is an increase in the absorption of plasma cholesterol to be synthesized again into bile, so that it will reduce cholesterol levels in blood plasma, by reducing degenerative cholesterol diseases such as cardiovascular disease can prevent and reduce its severity.

One source of food fiber is bengkuang, and one source of anthocyanin is the red dragon fruit. Jicama contains vitamin C, calcium, phosphorus, and fiber that are needed by the body. Bengkuang is one of the 
tubers that is easily found, especially in the area of responsibility other than that bengkuang is a good source of food fiber for digestion and can be used as an alternative to functional food compilers. ${ }^{7}$ One of the food fiber is Inulin; Inulin is a polysaccharide that is classified in the carbohydrate group. Inulin has many benefits for the body, including being used as a prebiotic by reducing the number of pathogenic bacteria in the body, increasing immunity, and reducing the risk of osteoporosis. ${ }^{8}$ Jicama contains $6.52 \%$ inulin. $^{9}$

Red dragon fruit has a higher antioxidant content compared to white dragon fruit. Red dragon fruit contains anthocyanins as antioxidants. Anthocyanin levels range from $8.8 \mathrm{mg} /$ $100 \mathrm{gr}$ of dragon fruit. ${ }^{10}$

One of the problems with fresh food is that it is easily damaged. Fruit that is damaged cannot be consumed because it can reduce acceptance. Velva product was chosen because this dessert is suitable for the tropical climate of Indonesia, besides it is more effective and efficient. After all, one product contains a variety of nutrients, especially anthocyanin and Inulin fiber. After all, it is made from several kinds of food ingredients, namely dragon fruit and bengkuang.

Velva fruit is one type of frozen dessert food made from fruits and frozen with ice cream freezing tools that have low-fat content because it does not use milk fat, so it is suitable for consumption by vegetarians and people on a low-fat diet. Another advantage of fruit Velva is its vitamin content because it comes from fresh fruits. ${ }^{11}$ Velva of good quality requires the right balance to find the right balance.

According to research
conducted by Azhoranezar
Ramadhani and Enny Probosari,
giving $250 \mathrm{ml}$ of bengkuang juice
from $320 \mathrm{~g}$ of bengkuang for 21 days
in $2840-50$-year-old women proved
to be able to reduce triglyceride
levels by $14.93 \mathrm{mg} / \mathrm{dl} .{ }^{12}$ According to

research by Edgar David Sigarlaki and Agustyas Tjiptaningrum, red dragon fruit (Hylocereus ployrhzus) has a substance that plays a role in reducing total cholesterol levels, namely anthocyanins. Anthocyanins can reduce total cholesterol levels by inhibiting cholesterol ester transfer protein (CETP) and inhibiting the HMG-CoA reductase enzyme. Red dragon fruit has the effect of reducing total cholesterol levels [5]. The purpose of this study was to obtain the product of Dragon Yam Bean Velva as a functional food and alternative food high inulin fiber and analyze aspects of the quality of Dragon Yam Bean Velva, which includes organoleptic properties, inulin fiber content, and anthocyanin.

\section{METHOD}

This research is an experimental study with a completely randomized design (CRD). The level of preference was obtained from the hedonic test, and anthocyanin levels and fiber levels were obtained from laboratory tests. The independent variable in this study is the comparison between dragon fruit and Bengkuang. There are three balances, namely: a) Formula 1 is a sample of Dragon Yam Bean Velva with a balance of $30 \%: 70 \%$, b) Formula 2 is a sample of Dragon Yam Bean Velva with a balance of $70 \%: 30 \%$, and Formula 3 is a sample of Dragon Yam Bean Velva with a balance of $50 \%$ : $50 \%$, which influences the dependent variable, namely the level of panelist preference on organoleptic properties (color, aroma, taste, texture) as well as anthocyanin and fiber content.

The study was conducted from September 2018 to February 2019. Research to determine the level of preference was tested on 30 rather trained panelists who were students and lecturers at the Department of Nutrition at the Health Ministry of Health, Bandung, and carried out at the Food 
Technology Laboratory of the Department of Nutrition at the Health Ministry at the Bandung Health Ministry. Testing of anthocyanin levels in the Food Technology Laboratory of the Pasundan University Faculty of

\section{RESULT}

The first stage carried out in the preliminary research is to determine the ratio of the main ingredients, namely fruit. Selected comparisons are 70:30,
Engineering as well as fiber content testing was conducted at the PT Saraswanti Indo Genetech Laboratory, Bogor. Data were analyzed using the Kruskal Wallis test and continued with the Mann Whitney test.

$30: 70$, and $50: 50$. The next step is to conduct a trial to get the desired product quality and to modify it by combining the fruit with the tuber. Next, make a recipe at each balance

Table 1

Formula Dragon Yam Bean Velva

\begin{tabular}{|c|c|c|c|c|}
\hline \multirow[b]{2}{*}{ No } & \multirow[b]{2}{*}{ Ingredient } & Formula 1 & \multirow{2}{*}{$\begin{array}{l}\text { Formula } 2 \\
\text { Dragon Fruit } \\
\text { Bengkuang }\end{array}$} & Formula 3 \\
\hline & & $\begin{array}{l}\text { Dragon Fruit : } \\
\text { Bengkuang } \\
30 \%: 70 \%\end{array}$ & & $\begin{array}{l}\text { Dragon Fruit } \\
\text { Bengkuang } \\
50 \%: 50 \%\end{array}$ \\
\hline 1 & Bengkuang & $467 \mathrm{~g}$ & $200 \mathrm{~g}$ & $334 \mathrm{~g}$ \\
\hline 2 & Dragon Fruit & $200 \mathrm{~g}$ & $467 \mathrm{~g}$ & $334 \mathrm{~g}$ \\
\hline 3 & Sugar (15\%) & $150 \mathrm{~g}$ & $150 \mathrm{~g}$ & $150 \mathrm{~g}$ \\
\hline 4 & Sitrat Acid $(0.1 \%)$ & $1 \mathrm{~g}$ & $1 \mathrm{~g}$ & $1 \mathrm{~g}$ \\
\hline 5 & CMC $(0.75 \%)$ & $7.5 \mathrm{~g}$ & $7.5 \mathrm{~g}$ & $7.5 \mathrm{~g}$ \\
\hline
\end{tabular}

In table 1, the Naga Bengkuang Bean Velva formula with three balances. Each formula has a different ratio of dragon fruit and yam fruit composition. In contrast, the use of other raw materials such as sugar, citric acid, and carboxyl methyl cellulose (CMC) has no difference. The function of the stabilizer used in making Velva is to increase the thickness and smooth the texture [40]. Carboxyl methylcellulose concentration for making Velva is $0.75 \%$ by weight of puree. ${ }^{40}$

Besides CMC, another ingredient used in the same amount is citric acid. According to research conducted by Yudhistira (2018) in the manufacture of super red dragon fruit Velva, citric acid used was as much as $0.1 \%$ [39]. The addition of citric acid to the product is intended to provide a slightly acidic taste to improve flavor. One recipe for Dragon Yam Bean Velva produces $600 \mathrm{~g}$ of Velva.

Hedonic Properties Test Results

The hedonic test was carried out on 30 rather trained panelists. The target of the panelists who were rather well trained were students of the Bandung Health Polytechnic who had received food technology courses. The hedonic test was carried out on four aspects, namely color, taste, aroma, and texture, and five measurement scales were set for each aspect, namely dislike, somewhat like, neutral, like, and very like. Statistical test results on the normality test showed the value of $P=$ 0.001 ( $p a \leq 0.05$ ) for aspects of color, taste, aroma, and texture, which means the data was not normally distributed. The data was processed with the Kruskal-Wallis statistical test.

\section{Dragon Yam Bean Velva Color Assessment Results}

An assessment of the color aspects of the Dragon Yam Bean Velva product was carried out on 30 rather trained panelists using a hedonic quality test method. The following are the results of an assessment of the color aspects of Dragon Yam Bean Velva products. 
Table 2

Distribution of Panelist Assessments on the Color of Dragon Yam Bean Velva

\begin{tabular}{lcccccccc}
\hline & \multicolumn{1}{c}{ Balance } & \multicolumn{1}{c}{ Total } \\
\cline { 2 - 7 } Scale & $\mathrm{F} 130: 70$ & $\mathrm{~F} 270: 30$ & $\mathrm{~F} 350: 50$ & & \\
\cline { 2 - 7 } & 0 & 0 & 0 & 0 & 0 & 0 & 0 & 0.00 \\
\hline Dislike & 5 & 16,7 & 0 & 0 & 0 & 0 & 5 & 5,56 \\
Rather Like & 15 & 50 & 3 & 10 & 5 & 16,7 & 23 & 25,56 \\
Neutral & 9 & 30 & 10 & 33,3 & 15 & 50 & 34 & 37,78 \\
Like & 1 & 3.3 & 17 & 56,7 & 10 & 33,3 & 28 & 31,11 \\
Very Like & 30 & 100 & 30 & 100 & 30 & 100 & 90 & 100 \\
\hline
\end{tabular}

Based on table 2, it can be seen that the highest level of panelists' preference for the color of Dragon Yam Bean Velva products in formula 2 is 17 panelists $(56.7 \%)$ said they very liked, ten panelists (33.3\%) said they liked. Three panelists $(10 \%)$ declare neutral. Formula 3 , as many as ten panelists $(33.3 \%)$ said they very liked, 15 panelists $(50 \%)$ said they liked, and five panelists (16.7\%) said they were neutral. Formula 1 of 1 panelist (3.3\%) said they very liked, nine panelists (30\%) said they liked, 15 panelists (50\%) said were neutral, and five panelists (16.7\%) said they rather like.

Based on these data, the color in formula 2 with a balance of $70 \%$ dragon fruit: $30 \%$ bengkuang is the most preferred. When viewed from the percentage of likes and likes, they add up to $90 \%$ with a panelist of 27 people. A description of the average panelist's assessment of the color of Dragon Yam Bean Velva products can be seen in Figure 1

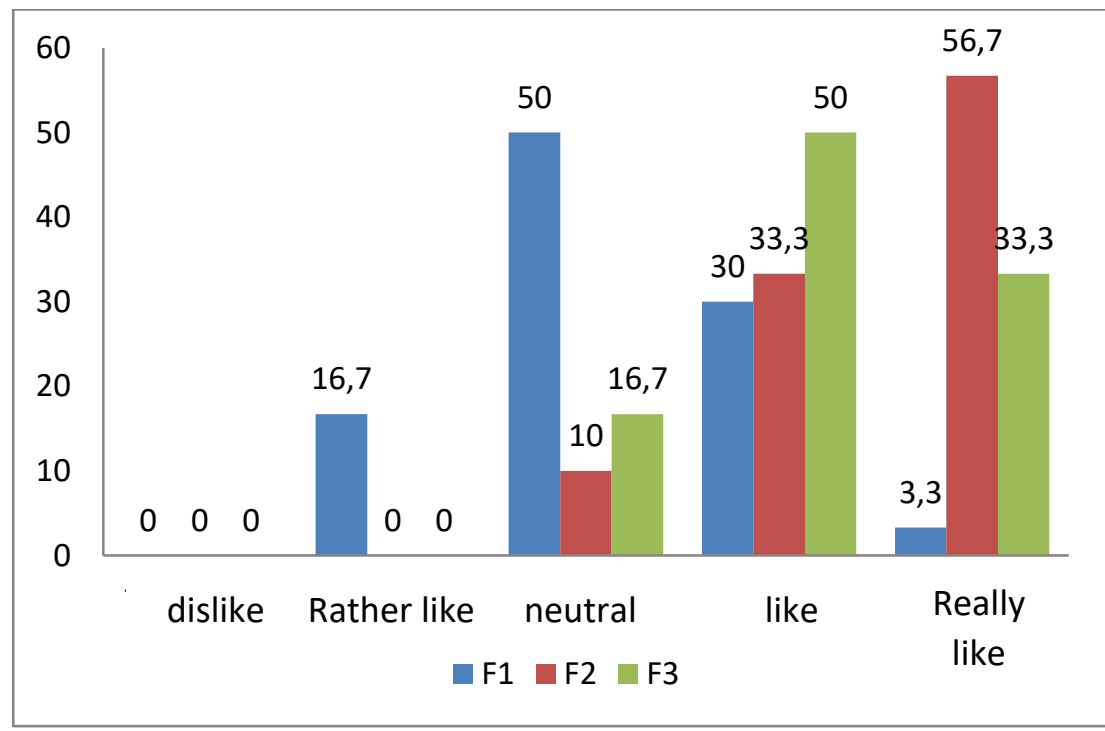

Figure 1

Distribution of Panelist Assessments on the Color of Dragon Yam Bean Velva

In the Kruskal Wallis test results obtained $p=0.001$ ( $p \leq 0.05)$, which means that there are significant differences in the color aspects of the three formulas of Dragon Yam Bean
Velva. Mann Whitney test was then performed to determine the differences between formulas. Following are the results of the Mann Whitney test in Table 5.3 
Table 3

Mann Whitney Test Results on the Color of Dragon Yam Bean Velva

\begin{tabular}{|c|c|c|c|}
\hline \multicolumn{2}{|c|}{ Intervention } & $\mathrm{P}$ Value & Conclusion \\
\hline $\mathrm{F} 1$ & $\mathrm{~F} 2$ & 0,001 & There are Meaningful Differences \\
\hline $\mathrm{F} 1$ & F3 & 0,001 & There are Meaningful Differences \\
\hline $\mathrm{F} 2$ & F3 & 0,082 & There Are No Meaningful Differences \\
\hline
\end{tabular}

Based on table 3, information is obtained that there is a statistically significant difference between $\mathrm{F} 1$ and $\mathrm{F} 2$ and $F 1$ and $F 3$ with $P \leq \alpha(0.05)$. But there is no significant difference between F2 and F3 with a value of $p=$ 0.08 ( $p>\alpha$ 0.05). Based on these data, the colors in formula 1 (30\% dragon fruit: $70 \%$ bengkuang) have a statistically significant difference.

\section{Dragon Yam Bean Velva taste assessment results}

An assessment of the taste aspects of the Dragon Yam Bean Velva product was carried out on 30 panelists rather than trained using the hedonic quality test method. The following are the results of an assessment of the taste aspects of Dragon Yam Bean Velva products.

Table 4

Distribution of Judges' Assessment of Dragon Yam Bean Velva's Taste

\begin{tabular}{|c|c|c|c|c|c|c|c|c|}
\hline \multirow{3}{*}{ Scale } & \multicolumn{6}{|c|}{ Balance } & \multirow{2}{*}{\multicolumn{2}{|c|}{ Total }} \\
\hline & \multicolumn{2}{|c|}{ F1 30:70 } & \multicolumn{2}{|c|}{ F2 70:30 } & \multicolumn{2}{|c|}{ F3 50:50 } & & \\
\hline & $\mathbf{n}$ & $\%$ & $\mathbf{n}$ & $\%$ & $\mathbf{n}$ & $\%$ & $\mathrm{n}$ & $\%$ \\
\hline Dislike & 0 & 0 & 0 & 0 & 0 & 0 & 0 & 0.00 \\
\hline Rather Like & 5 & 16,7 & 2 & 6,7 & 1 & 3,3 & 8 & 8,89 \\
\hline Neutral & 9 & 30 & 2 & 6,7 & 5 & 16,7 & 16 & 17,78 \\
\hline Like & 11 & 36,7 & 16 & 53,3 & 12 & 40 & 39 & 43,33 \\
\hline Very like & 5 & 16,7 & 10 & 33,3 & 12 & 40 & 27 & 30,00 \\
\hline Total & 30 & 100 & 30 & 100 & 30 & 100 & 90 & 100 \\
\hline
\end{tabular}

Based on table 4, it can be seen that the highest level of preference for the taste of Dragon Yam Bean Velva products in formula 2.There is 16 panelists $(53.3 \%)$ who like it, ten panelists $(33.3 \%)$ say they very like it, two panelists $(6,7 \%)$ said they were neutral. Two panelists $(6.7 \%)$ said they liked it. Formula 3 as many as 12 panelists (40\%) said they liked, 12 panelists $(40 \%)$ said they very liked, five panelists $(16.7 \%)$ said were neutral, and one panelist (3.3\%) said they rather like. Formula 1 as many as 11 panelists
(36.3\%) said they liked, five panelists $(16.7 \%)$ said they very liked, nine panelists $(30 \%)$ said were neutral, and five panelists (16.7\%) said they rather like.

Based on these data, the taste in formula 2 with a balance of $30 \%$ bengkuang: $70 \%$ of the most preferred dragon fruit. When viewed from the percentage of likes and likes, there is $86.6 \%$ with 26 panelists. A description of the average panelist's assessment of the taste of Dragon Yam Bean Velva products can be seen in Figure 5.2 
Vol.12 No. 1. Mei 2020

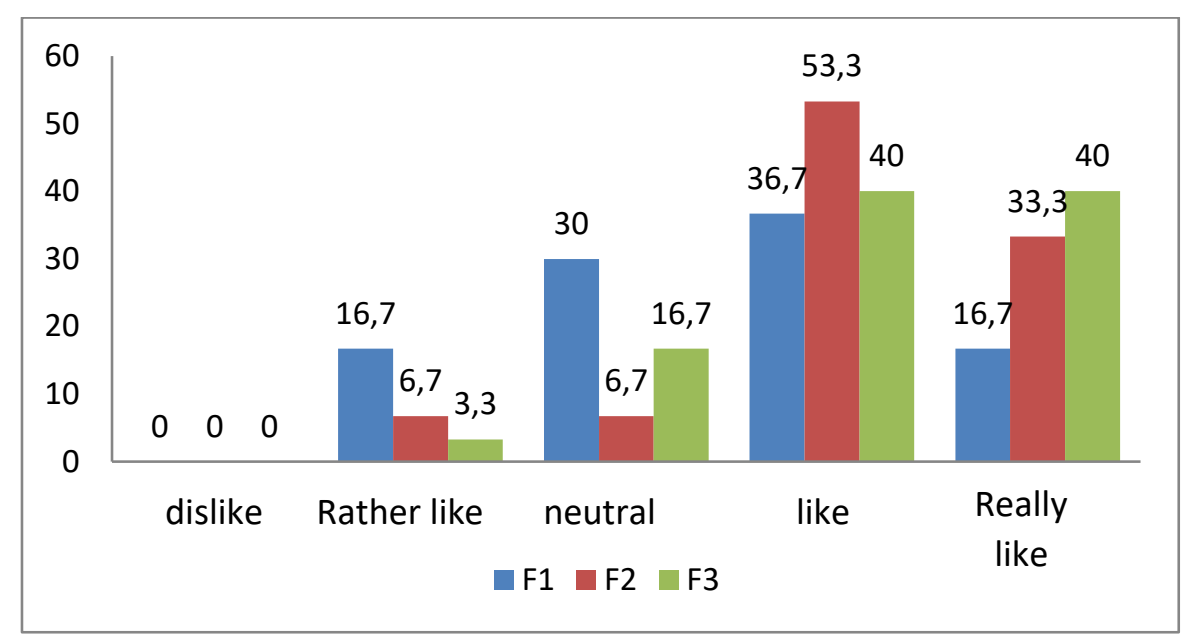

Figure 2

Distribution of Judges' Assessment of Dragon Yam Bean Velva's Taste

In the Kruskal Wallis test, results obtained $p=0.013<0.05$, which means that there are significant differences in taste aspects in the three formulas of Dragon Yam Bean Velva. Mann Whitney test was then performed to determine the differences between formulas. Following are the results of the Mann Whitney test in table 5

Table 5

Mann Whitney Test Results on the Taste of Dragon Yam Bean Velva

\begin{tabular}{llcl}
\hline \multicolumn{2}{l}{ Intervention } & P-Value & Conclusion \\
\hline F1 & F2 & 0,011 & There are Meaningful Differences \\
F1 & F3 & 0,011 & There are Meaningful Differences \\
F2 & F3 & 0,872 & There Are No Meaningful Differences \\
\hline
\end{tabular}

Based on table 5, the test results show that there are statistically significant differences between $\mathrm{F} 1$ and $F 2$ and $F 1$ and F3 with p-value $\alpha(0.05)$. but there is no significant difference between F2 and F3 with a value of $p=$ $0.87(p>\alpha$ (0.05). Based on these data, the taste in formula 1 with a balance of $30 \%$ dragon fruit: $70 \%$ bengkuang, there is a statistical difference.
The results of the assessment of the aroma of Dragon Yam Bean Velva

An evaluation of the aroma aspects of Dragon Yam Bean Velva products was carried out on 30 panelists who were somewhat trained using the hedonic quality test method. The following are the results of an evaluation of the aroma aspects of Dragon Yam Bean Velva products.

Table 6

Distribution of Judges' Assessment of the Aroma of Dragon Yam Bean Velva

\begin{tabular}{|c|c|c|c|c|c|c|c|c|}
\hline \multirow{3}{*}{ Scale } & \multicolumn{6}{|c|}{ Formula } & \multirow{2}{*}{\multicolumn{2}{|c|}{ Total }} \\
\hline & \multicolumn{2}{|c|}{ F1 30:70 } & \multicolumn{2}{|c|}{ F2 70:30 } & \multicolumn{2}{|c|}{ F3 50:50 } & & \\
\hline & $n$ & $\%$ & $n$ & $\%$ & $\mathbf{N}$ & $\%$ & $n$ & $\%$ \\
\hline Dislike & 1 & 3.3 & 0 & 0 & 0 & 0 & 1 & 1.11 \\
\hline Rather Like & 5 & 16.7 & 0 & 0 & 1 & 3.3 & 6 & 6.67 \\
\hline Neutral & 14 & 46.7 & 9 & 30 & 9 & 30 & 32 & 35.56 \\
\hline Like & 9 & 30 & 14 & 46.7 & 15 & 50 & 38 & 42.22 \\
\hline Very like & 1 & 3.3 & 7 & 23.3 & 5 & 16.7 & 13 & 14.44 \\
\hline
\end{tabular}


Vol.12 No. 1. Mei 2020

\begin{tabular}{lllllllll}
\hline Total & 30 & 100 & 30 & 100 & 30 & 100 & 90 & 100 \\
\hline
\end{tabular}

Based on table 6, it can be seen that the highest level of preference for the panelists for the aroma of Dragon Yam Bean Velva products in formula 3.There were 15 panelists $(50 \%)$ said they liked. $16.7 \%$ said they very liked it, $30 \%$ stated neutrally, and $3.3 \%$ said they rather liked it. Formula 2, as many as 14 panelists (46.7\%) said they liked, seven panelists $(23.3 \%)$ said they very liked it, and nine panelists (30\%) said they were neutral. Formula 19 panelists $(30 \%)$ said they liked, one panelist (3.3\%) said they very liked, 14 panelists (46.7\%) said were neutral, five panelists (16.7\%) said they rather like, and one panelist (3.3\%) expressed dislike.

Based on these data, the aroma in formula 2 with a balance of $70 \%$ dragon fruit: $30 \%$ bengkuang is the most preferred. Twenty-one panelists $(70 \%)$ said they like and very like the formula. A description of the average panelist's assessment of the aroma of Dragon Yam Bean Velva products can be seen in Figure 3

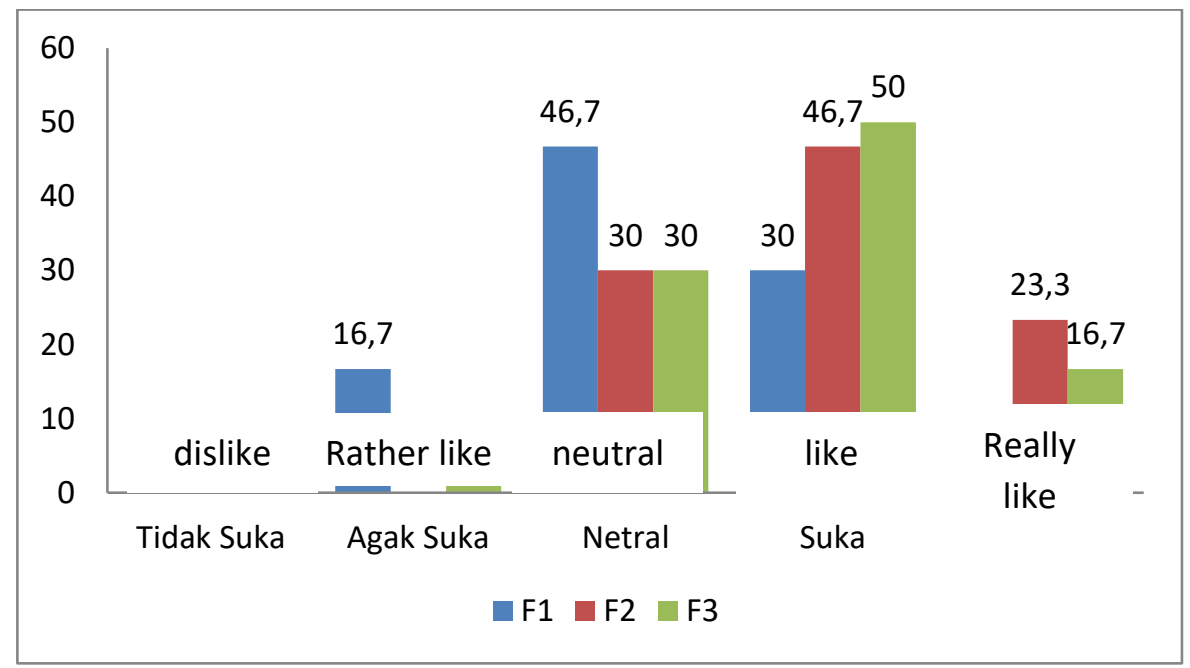

Figure 3

Distribution of Judges' Assessment of the Aroma of Dragon Yam Bean Velva

Table 7

Mann Whitney Test Results on the Aroma of Dragon Yam Bean Velva

\begin{tabular}{llll}
\hline \multicolumn{2}{l}{ Intervention } & P-Value & Conclusion \\
\hline F1 & F2 & 0,011 & There are Meaningful Differences \\
F1 & F3 & 0,03 & There are Meaningful Differences \\
F2 & F3 & 0,554 & There Are No Meaningful Differences \\
\hline
\end{tabular}

In the Kruskal Wallis test results obtained $p=0.001$ ( $p \leq 0.05$ ), which means that there are significant differences in taste aspects in the three formulas of Dragon Yam Bean Velva. Furthermore, the Mann Whitney test is performed to determine the differences between formulas. The following are the results of the Mann Whitney test in Table 7.
Based on table 7, the test results are obtained that there are statistically significant differences between $\mathrm{F} 1$ and $F 2$ and $F 1$ and $F 3$ with $p \leq \alpha(0.05)$. But there is no significant difference between F2 and F3 with $p>\alpha(0.05)$. Based on these data, the aroma in formula 1 with a balance of $30 \%$ dragon fruit: $70 \%$ bengkuang, there are statistical differences 


\section{Dragon Yam Bean Velva texture assessment results}

An assessment of the texture aspects of the Dragon Yam Bean Velva product was carried out on 30 rather trained panelists using a hedonic quality test method. The following are the results of an assessment of the texture aspects of Dragon Yam Bean Velva products.

Table 8

Distribution of Judges' Assessment of the Texture of Dragon Yam Bean Velva

\begin{tabular}{|c|c|c|c|c|c|c|c|c|}
\hline \multirow{3}{*}{ Scale } & \multicolumn{6}{|c|}{ Formula } & \multirow{2}{*}{\multicolumn{2}{|c|}{ Total }} \\
\hline & \multicolumn{2}{|c|}{ F1 30:70 } & \multicolumn{2}{|c|}{ F2 70:30 } & \multicolumn{2}{|c|}{ F3 50:50 } & & \\
\hline & $\mathbf{n}$ & $\%$ & $\mathbf{n}$ & $\%$ & $\mathbf{n}$ & $\%$ & $\mathbf{n}$ & $\%$ \\
\hline Dislike & 0 & 0 & 0 & 0 & 1 & 3.3 & 1 & 1.11 \\
\hline Rather Like & 2 & 6.7 & 0 & 0 & 1 & 3.3 & 3 & 3.33 \\
\hline Neutral & 8 & 26.7 & 2 & 6.7 & 4 & 13.3 & 14 & 15.56 \\
\hline Like & 15 & 50 & 20 & 66.7 & 19 & 63.3 & 54 & 60.00 \\
\hline Really like & 5 & 16.7 & 8 & 26.7 & 5 & 16.7 & 18 & 20.00 \\
\hline Total & 30 & 100 & 30 & 100 & 30 & 100 & 90 & 100 \\
\hline
\end{tabular}

Based on table 8 , it can be seen that the highest level of panelists' preference for the taste of I products in formula 2 was 20 panelists $(66.7 \%)$ said they liked, eight panelists $(26.7 \%)$ said they very liked. Two panelists $(6,7 \%)$ stated neutrally. Formula 3 with 19 panelists $(63.3 \%)$ said they liked, five panelists $(16.7 \%)$ said they very liked, four panelists (13.3\%) said were neutral, one panelist $(3.3 \%)$ said rather like, and one panelist (3.3\%) said they did not like it. Formula 115 panelists $(50 \%)$ said they liked, five panelists $(16.7 \%)$ said they very liked, eight panelists (26.7\%) said were neutral, and two panelists $(6.7 \%)$ said they rather like.

Based on these data, the texture in formula 2 with a balance of $70 \%$ dragon fruit: $30 \%$ bengkuang is the most preferred. When viewed from the percentage of likes and likes as much as $93.4 \%$ with a panelist of 28 people. A description of the average panelist's assessment of the texture of Dragon Yam Bean Velva products can be seen in Figure 4

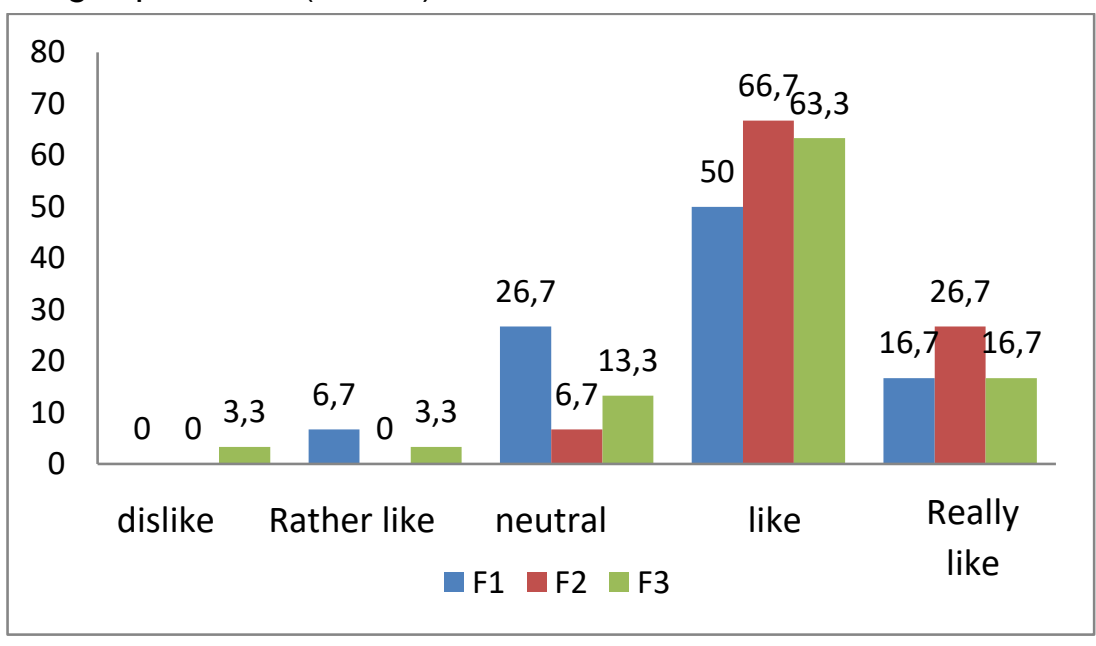

Figure 4

Distribution of Judges' Assessment of the Texture of Dragon Yam Bean Velva 
In the Kruskal Wallis test results obtained $p=0.076$ ( $p>0.05$ ), which means there is no significant difference in the texture aspects of the three formulas of Dragon Yam Bean Velva, so there is no need for further tests.

\section{Dragon Yam Bean Velva Nutrition Value Analysis Results}

Nutritional calculation of Dragon Yam Bean Velva is determined based on Velva with the highest level of panelist preference, namely formula 2 , with a balance of $30 \%$ bengkuang: $70 \%$ dragon fruit.

\section{Energy, Protein, Fat, and Carbohydrates}

Calculations are made using the Food Composition List (DKBM) based on the ingredients used in making Dragon Yam Bean Velva. In one recipe, Dragon Yam Bean Velva produced is seven servings weighing $80 \mathrm{~g}$ per portion. So that one serving size, there is one portion of Dragon Yam Bean Velva with a total weight of $80 \mathrm{~g}$. The nutritional content of Energy, Protein, Fat, and Carbohydrates of Dragon Yam Bean Velva products can be seen in table 9

Table 9

Dragon Yam Bean Velva Nutritional Value Per Serving Size

\begin{tabular}{|c|c|c|c|}
\hline $\begin{array}{l}\text { Nutritional } \\
\text { Substances }\end{array}$ & $\begin{array}{l}\text { Formula } 1 \\
\text { Dragon Fruit: } \\
\text { Bengkuang } \\
30 \%: 70 \%\end{array}$ & $\begin{array}{l}\text { Formula } 2 \\
\text { Dragon Fruit: } \\
\text { Bengkuang } \\
70 \%: 30 \%\end{array}$ & $\begin{array}{l}\text { Formula } 3 \\
\text { Dragon Fruit : } \\
\text { Bengkuang } \\
50 \%: 50 \%\end{array}$ \\
\hline Energy & 160.58 & 173,42 & 170,86 \\
\hline Protein & 1,65 & 1,78 & 1,72 \\
\hline Fat & 1,18 & 2,4 & 1,8 \\
\hline Carbohydrate & 36,49 & 34,84 & 35,69 \\
\hline
\end{tabular}

Table 9 is the macronutrient content for all three formulas. However, based on the level of preference, the nutritional value of further research is formula 2 , with a ratio of $70 \%$ dragon fruit: $30 \%$ bengkuang. The contribution of Dragon Yam Bean Velva serving size is determined based on the results of calculations using the Food Composition List (DKBM) compared to the adequacy of nutrients for distilled foods obtained from ALG 2018. Contributions can be seen in table 10.

Table 10

Dragon Yam Bean Velva's Contribution to the Battle of Nutrition Adequacy

\begin{tabular}{lcccc}
\hline $\begin{array}{l}\text { Nutritional } \\
\text { Substances }\end{array}$ & $\begin{array}{l}\text { Adequacy } \\
\text { of snacks }\end{array}$ & $\begin{array}{l}\text { Formula 1 } \\
\text { Dragon Fruit: } \\
\text { Bengkuang } \\
30 \%: 70 \%\end{array}$ & $\begin{array}{l}\text { Formula 2 } \\
\text { Dragon Fruit: } \\
\text { Bengkuang } \\
70 \%: 30 \%\end{array}$ & $\begin{array}{l}\text { Formula 3 } \\
\text { Dragon Fruit } \\
\text { Bengkuang } \\
50 \%: 50 \%\end{array}$ \\
\hline Energy & $215 \mathrm{kcal}$ & 74,69 & 80,66 & 79,47 \\
Protein & $8,0 \mathrm{~g}$ & 20,63 & 22,25 & 21,50 \\
Fat & $5,9 \mathrm{~g}$ & 20,00 & 40,68 & 30,51 \\
Carbohydrate & $32,25 \mathrm{~g}$ & 113,15 & 108,03 & 110,67 \\
\hline
\end{tabular}

Based on table 10 that the Dragon Yam Bean Velva formula 2 can meet the energy adequacy of $80.66 \%$, protein $22.25 \%$, fat $40.68 \%$, and carbohydrates $108.03 \%$. Energy 
Adequacy has met the adequacy of a one-time snack for adults.

\section{Anthocyanin Level Test Results}

The anthocyanin content test was carried out on a selected product in terms of color, taste, aroma, and texture, namely formula 2 with a balance of $70 \%$ dragon fruit: $30 \%$ bengkuang. The test was conducted at the Food Technology Laboratory of Pasundan University, Bandung. Tests are carried out using methods. The results of testing Anthocyanin levels can be seen in table 11.

Table 11

Dragon Yam Bean Velva Anthocyanin Level Test Results

\begin{tabular}{llll}
\hline Sample & Kadar & Result & Unit \\
\hline F2 30\%:70\% & Anthocyanin & 60,40 & $\mathrm{mg} / \mathrm{L}$ \\
\hline
\end{tabular}

\section{Inulin Level Test Results}

Inulin Fiber content test is conducted on a selected product in terms of color, taste, aroma, and texture, which is formula 2 with a balance of $30 \%$ bengkuang: $70 \%$ dragon fruit. Inulin Fiber content testing is carried out using the literature method.

According to the results of an analysis conducted by Mulyani in

\section{DISCUSSION}

Preliminary research was conducted to test the modification of the recipe and to try out the balanced formulation-tests with various combinations selected based on the ratio 70:30, 30:70, and 50:50.

Modification of recipes is obtained from the original recipe Velva fruit. Modification of the recipe is done by adding bengkuang tuber ingredients. Next, make a recipe in each balance. The ingredients that follow the percentage ratio are only dragon fruit and bengkuang. Sugar, water, CMC, and citric acid use the same weight in each balance. It is intended to see a significant difference between the balance of dragon fruit and bengkuang with Dragon Yam Bean Velva. The use of CMC or Carboxyl Methyl Cellulosa serves to refine the Velva texture. In contrast, the addition of citric acid serves to provide a biting taste and as an amplifier of smell and taste. The
Kamsina (2014), it was stated that tuber bengkuang contained $6.512 \%$ inulin and $4.41 \%$ filtrate [9]. Based on this research, the inulin content derived from bengkuang tubers in formula 2 with a balance of $70 \%$ dragon fruit: $30 \%$ bengkuang is $13 \mathrm{~g}$ for one recipe so that for one serving size is $2.1 \mathrm{~g}$.

Selection of supporting raw materials such as CMC, citric acid, and sugar are selected based on market availability, do not use specific brand specifications because, in sales, there are no brands, especially for CMC and citric acid.

The main research was carried out in two stages, the first stage, namely testing the organoleptic nature (hedonic test) and the second stage, namely testing the levels of anthocyanin and inulin fiber levels. Organoleptic testing with a hedonic test was carried out on February 4, 2019, involving 30 rather trained panelists consisting of 5-7 semester students of the Nutrition Department of the Health Ministry of Health, Bandung. The main research was carried out in two stages, the first stage, namely testing the organoleptic nature (hedonic test) and the second stage, namely testing the levels of anthocyanin and inulin fiber levels. Organoleptic testing with a hedonic test was carried out on February 4, 2019, 
involving 30 rather trained panelists consisting of 5-7 semester students of the Nutrition Department of the Health Ministry of Health, Bandung.

The process of making products is done at the Food Technology Laboratory of the Nutrition Department in Bandung. The manufacturing procedure consists of peeling bengkuang tubers, weighing, and washing them. After that, weighing on the dragon fruit and weighing other ingredients and smoothing and mixing it using a blender. Then process it using an ice cream maker. The second phase of the research was conducted on April 10, 2019, at the Food Technology Laboratory of Pasundan University, Bandung. Whereas to find out the levels of Inulin and do with the literature test.

Product

Description

Velva fruit is one type of frozen dessert food made from fruits and frozen with ice cream freezing tools that have low-fat content because it does not use milk fat, so it is suitable for consumption by vegetarians and people on low-fat diets. ${ }^{11}$

Dragon fruit comes from dry tropical climates. Its natural habitat is in Mexico, Central America, and northern South America. H. polyrhizus contains flavonoids and polyphenols, which have antioxidant activity to bind to free radicals in biological systems. Also, $\mathrm{H}$. polyrhizus has properties as a counterweight to blood sugar levels, prevention of colon cancer, protective oral health, prevention of bleeding, and medication for vaginal discharge. ${ }^{47}$ Antioxidants found in dragon fruit are anthocyanins. Anthocyanin is a natural pigment that is commonly found in plants that are red and purple. ${ }^{61}$ The anthocyanin pigment itself, aside from being used as a coloring agent, is also a good antioxidant. ${ }^{48}$ Red dragon fruit is the choice for making Velva because it has a high anthocyanin content and is easily found.
Bengkuang is a root plant whose tubers can be consumed. In Indonesia, bengkuang cultivation is found on the island of Java [43]. Bengkuang has a fairly high water content of around 86$90 \%{ }^{44}$

Inulin has many uses, including being used as a prebiotic that benefits intestinal health by inhibiting the growth of pathogenic bacteria, increasing immunity, improving digestion, reducing constipation, reducing the risk of colon cancer, and regulating the concentration of the hormones insulin and glucagon. ${ }^{31}$ Nutritional content in every 100 grams of bengkuang contains $55 \mathrm{kcal}$ of energy, 1.4 grams of protein, 0.2 grams of fat, 12.8 grams of carbohydrates, $15 \mathrm{mg}$ of calcium, $18 \mathrm{mg}$ of phosphorus, vitamin $\mathrm{A}$ $0 \mathrm{SI}, 0.04 \mathrm{mg}$ of vitamin B1, vitamin C 20 $\mathrm{mg}$ and iron $0.6 \mathrm{mg}$ and sweetness in bengkuang tubers derived from an oligosaccharide called Inulin [49]. Bengkuang tubers become the choice as one of the main raw materials for making Velva because it has a high content of inulin fiber and is easily found.

The naming of this product is taken from the combination of the names of the main raw materials, namely dragon fruit and bengkuang, which is made into Velva so that the name obtained is Dragon Yam Bean Velva. Dragon Yam Bean Velva is Velva made from dragon fruit and bengkuang tubers as the main ingredients. In one recipe, the Velva produced weighs $100 \mathrm{~g}$ per portion, which is served in a mediumsize cup, this product has a sweet and slightly sour taste, has a distinctive aroma of dragon fruit, and is magentacolored dragon fruit. Its texture is soft but easy to melt if placed at room temperature. The storage conditions of this Velva are placed in the cooler. This product can be eaten directly or can be stored in a refrigerator with a closed container. Here are the final results of Dragon Yam Bean Velva. 


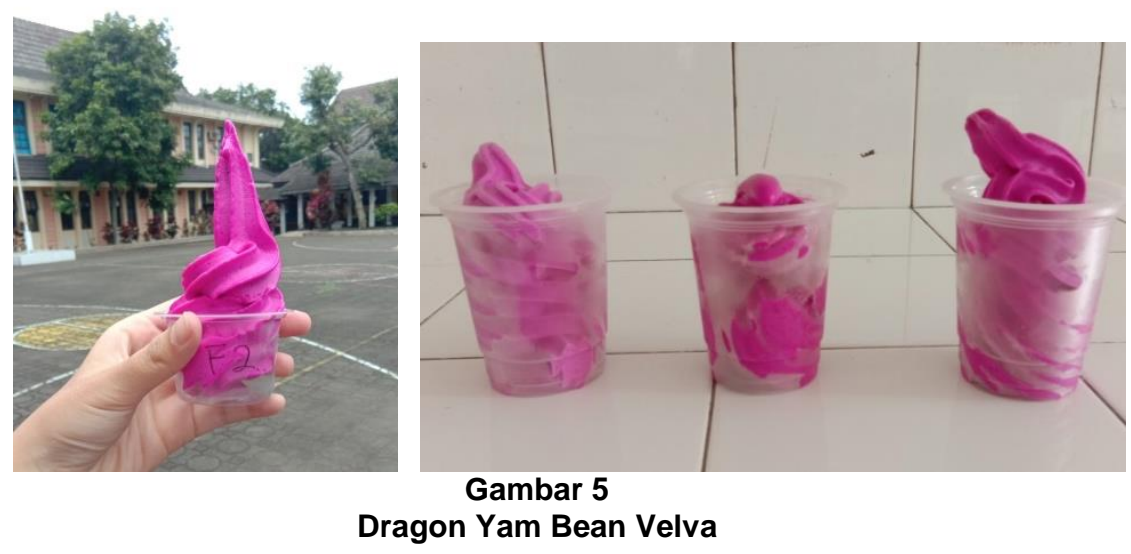

This product is made by mixing dragon fruit and tuber bengkuang with the hope of adding nutritional value and effectiveness in one product that is rich in antioxidants, namely anthocyanin and inulin fiber.

\section{Organoleptic Properties of Dragon Yam Bean Velva \\ The color of Dragon Yam Bean Velva}

Color has an important role in the reception of a food product and determines the level of liking for food. The higher the concentration of dragon fruit in the recipe, the higher the level of color preference for the product.

From the results of the panelists' assessment, the level of liking for the color of Dragon Yam Bean Velva was seen from the two assessment categories, namely likes and likes. In formula 1, the number of likes and likes is $33 \%$, in formula 2 , the number of likes and likes is $90 \%$, and in formula 3, the number of likes and likes is $83.3 \%$. Among these three formulas, it can be seen that formula 2 is the formula chosen in terms of color aspects, with the highest percentage among the other three formulas.

Kruskal Wallis statistical testing was conducted to determine the differences of each formula on the color of Dragon Yam Bean Velva. The test results showed $p=0.001$ ( $p \leq 0.05)$, which means that there are significant differences in organoleptic properties based on the color parameters between the three formulas of Dragon Yam Bean Velva. Then the test continued using the
Mann Whitney test. Statistically significant results were obtained between formula 1 and formula 2, as well as formula 1 and formula 3 with values $(p \leq 0.05)$. However, there was no significant difference between formula 2 and formula 3 with values ( $p>0.05)$.

Based on these data the color in formula 2 with a balance of $30 \%$ bengkuang: $70 \%$ dragon fruit which has the highest percentage of hedonic tests on the color aspect $(90 \%)$ and has a significant difference with formula 1 , it makes formula 2 become the formula chosen in terms of color aspect. The color seen in the Dragon Yam Bean Velva comes from anthocyanin. Formula 2 is the chosen formula because it has the most dragon fruit composition compared to other formulas so that the anthocyanins contained in formula 2 as dyes are more than other formulas. According to research conducted by Fajarwati (2017) states that citric acid can affect food color. The higher concentration of citric acid causes the color value to decrease [50]. However, in this product, the amount of citric acid added is very small so that the effect does not have much impact on the product. While the distinctive color of bengkuang is not too visible, this can be caused by the color of the white bengkuang or broken white so that the color of anthocyanin is the dominant color that is seen.

Taste of Dragon Yam Bean Velva

Taste and aroma are some of the characteristics to which sailing is 
connected. The taste can be known after the product is eaten. Flavors can be distinguished as salty, sweet, sour, bitter, and umami and are influenced by the ingredients used. From the results of the panelists' assessment, the level of liking for the taste of Dragon Yam Bean Velva was seen from the two assessment categories of likes and likes. In formula 1 , the number of likes and likes is $53.4 \%$, in formula 2 , the number of likes and likes is $86.6 \%$, and in formula 3 the number of likes and likes is $80 \%$. Among the three formulas, it can be seen that formula 2 is the formula chosen in terms of flavor aspects with the highest percentage, among other formulas.

From the results of the Dragon Yam Bean Velva hedonic test, the difference in taste looks very different between formula 1 fan formula 2 . In the recipe, the sugar balance in each formula is $20 \%$, so that the difference in different taste aspects can be seen influenced by the diverse composition of fruit and tubers. One ingredient that contributes to sweet taste is bengkuang tubers because the sweet taste in bengkuang tubers comes from an oligosaccharide called Inulin [49]. In addition to the sweet taste caused by sugar and basic ingredients, namely dragon fruit and bengkuang, there is a sour taste. A citric acid is an option because it is more effective and efficient in its use compared to the use of lemons or lemon. The use of the comparison of citric acid compared with lemon juice is $1: 14$ which means that $1 \mathrm{~g}$ of citric acid is equal to $14 \mathrm{ml}$ of lemon juice. ${ }^{50}$

Formula 1 has the most bengkuang tuber composition compared to formula 2 and formula 3 so that the sweet taste increases in formula 1. However, a less sweet taste like that of formula 2 has become the choice of most panelists on Dragon Yam Bean Velva products. Kruskal's statistical test results Wallis was conducted to find out the differences between each should on the taste of Velva. The test results showed $p(0.005)<0.05$, which means that there are significant differences in organoleptic properties based on taste parameters between the three Dragon Yam Bean Velva formulas. Then the test continued using the Mann Whitney test. Statistically significant results were obtained between formula 1 and formula 2 as well as formula 1 and formula 3 with $p<\alpha$ (0.05). However, there was no significant difference between formula 2 and formula 3 with $p>\alpha(0.05)$. Based on these data, it was found that formula 2 became the chosen formula. It is seen from the hedonic test results the percentage of likes and likes is $86.6 \%$ (n $=24$ )

The aroma of Dragon Yam Bean Velva Aroma testing is considered important in the food industry because it can give results to product preferences. Besides, the aroma is closely related to the taste of a product. The aroma that arises is influenced by the ingredients used. In Dragon Yam Bean Velva products, ingredients that affect the aroma are bengkuang and dragon fruit. The results of the Velva aroma hedonic test with the like and very like the scale on formula 1 were $33.3 \%$, formula 2 was $70 \%$, and formula 3 was $66 \%$. From these data, it can be concluded that the panelist preference level is in formula 2.

The aroma of the Dragon Yam Bean Velva comes from two main raw materials, namely bengkuang and dragon fruit. The hedonic test results show that formula 1 has the lowest value on the liking level of the aroma aspect. Formula 1 has a higher concentration of bengkuang bean than formula 2 and formula 3 . It causes the distinctive aroma of bengkuang to become dominant in formula 1. The aroma of the selected formula, namely formula 2 , which has a dragon fruit composition is more dominant than the other formulas, the aroma the smell isn't too strong because the dragon fruit doesn't have a strong aroma. Also, the aroma of bengkuang in formula 2 is not too strong because of the small composition of 
bengkuang. In the manufacture of Dragon Yam Bean Velva, citric acid is used as a scent booster, but the use of stabilizers turns out to cause an odor in the dough, especially if the dough has a high thickness, causing the Velva aroma to become rather weak. ${ }^{50}$

Substances that cause a distinctive aroma on Velva come from the distinctive aroma of bengkuang, which contains phenols. Plants or fruits that contain phenols will have a fragrant aroma and a refreshing taste. ${ }^{55}$ According to Tunikasari (2015), the phenol content in each gram of bengkuang tubers is $140.76 \mathrm{mg}$. ${ }^{56}$ However, based on the hedonic test, phenols contained in bengkuang are less preferred by panelists; this can be caused by the aroma of phenol, which seems unpleasant to Velva. The results of the Kruskal Wallis statistical test were conducted to find out the differences between each formula on the Velva aroma. The test results show the value of $p=0.001$ ( $p \leq 0.05)$, which means that there are significant differences in organoleptic properties based on the aroma parameters between the three formulas of Dragon Yam Bean Velva. Then the test continued using the Mann Whitney test. Statistically significant results were obtained between formula 1 and formula 2 as well as formula 1 and formula 3 with $p<\alpha(0.05)$. However, there was no significant difference between formula 2 and formula 3 with $p>$ a (0.05). From these data, it can be concluded that products with fewer concentrations of bengkuang, preferably so that formula 2 , which has the least bengkuang concentration of $30 \%$, becomes the product of choice in terms of aroma aspects.

\section{The texture of Dragon Yam Bean Velva}

The texture is one of the parameters that can affect the acceptance and level of consumer preferences for a food product. The texture of the Dragon Yam Bean Velva product is influenced by the amount of
CMC used. The same amount of CMC is used in each formula so that there is no difference between formula 1, formula 2 and formula 3.

CMC or carboxyl

methylcellulose used in this product is $0.75 \%$. The function of the stabilizer used in making Velva is to increase the thickness and smooth the texture. Besides that, the stabilizer is used to prevent the formation of coarse ice crystals, form a soft structure, produce a uniform product, and provide better resistance to the search process and facilitate handling. The stabilizer can bind high water to smooth the texture, increase viscosity. ${ }^{51}$

The choice of stabilizer in the form of CMC is because this material dissolves easily in hot or cold water, can bind water, does not require aging to shorten the production process time, and the price is relatively cheap. ${ }^{51}$ In addition to CMC, sugar also plays a role in determining the texture because sugar can help prevent the formation of freezing ice crystals which are based because sugar molecules attract water molecules to produce a soft texture. ${ }^{52}$

Besides CMC, the raw material used can affect the Velva texture. It is due to the presence of starch in the main raw materials, namely bengkuang and dragon fruit. The raw material containing high starch is bengkuang with $63.62 \%$ starch content, while dragon fruit is $11.07 \% .^{57,58}$ The starch content found in bengkuang and dragon fruit can increase the viscosity so that the Velva yield capacity is longer. ${ }^{59}$

Then, another thing that can affect the Velva texture is the water content in the main raw material because of the greater the total solids, the lower the freezing point, and the smaller the amount of water that is frozen to reduce the ice cysts formed. ${ }^{39}$ In this study, the two main raw materials used contain high water content. Water content in dragon fruit is $82-89.4 \%$ while water content in bengkuang is 86$90 \%{ }^{39,9}$ Thus, high water content makes 
the Velva melting point low. Based on the hedonic test results on the texture aspect on the scale of likes and likes, formula 1 is $66.7 \%$, formula 2 is $93.4 \%$, and formula 3 is $80 \%$.

Kruskal Wallis statistical testing was conducted to find out the differences of each formula on the texture of Dragon Yam Bean Velva. The test results showed $p(0.005)>0.05$, meaning that there was no significant difference in organoleptic properties based on aroma parameters between the three formulas of Dragon Yam Bean Velva. Therefore there is no need for further testing. From these data, it can be concluded that formula 2 became the chosen formula because it has the highest percentage compared to formula 1 and formula 3 in terms of texture aspects.

\section{Dragon Yam Bean Velva Nutrition Value Analysis Results.

Energy, Protein, Fat, and
Carbohydrates

Based on the level of preference, observing the nutritional value was carried out on the selected formula, formula 2 , with a ratio of $30 \%$ bengkuang: $70 \%$ dragon fruit. The contribution of Dragon Yam Bean Velva serving size to macronutrient analysis is determined based on calculations using the DKBM (list of food ingredients composition) compared to the adequacy of nutrients for distilled foods obtained from AKG 2018.

In formula 2, the raw material that makes a significant contribution in meeting energy needs is sugar as much as $56 \%$ per serving $(98.5 \mathrm{kcal})$. The largest protein comes from dragon fruit as much as $1.32 \mathrm{~g}$. The biggest fat comes from dragon fruit as much as 2.4 g. Most of the carbohydrates come from sugar as much as $23.5 \mathrm{~g}$. Based on WNPG standards, which state minimum energy requirements of $\geq 80 \%$ and $<110 \%$ so that formula 2 becomes the chosen formula because it can meet the needs of one meal snack.
According to research conducted by Sumarni, Muzakir, and Tamrin (2017) about the effect of CMC on the nutritional value of ketapang milk, namely by adding CMC, the levels of protein, glucose, and fat are reduced [60]. So this product is suitable to be given on a low-fat diet.

\section{Dragon Yam Bean Velva's Anthocyanin content}

Based on the results of anthocyanin tests conducted at the laboratory of Pasundan University in Bandung, obtained the amount of anthocyanin in the product is $60.40 \mathrm{mg} /$ $\mathrm{L}$, which means that in one liter of Velva anthocyanin content is $60.40 \mathrm{mg}$. While the content of anthocyanin in one serving amounted to $4.23 \mathrm{mg}$.

Food intake containing anthocyanin of $2-400 \mathrm{mg} / \mathrm{kg}$ body weight can protect this form of oxidative stress [53]. Anthocyanin requirement is calculated based on the average body weight of Indonesian adults is $52 \mathrm{~kg}$, so that the anthocyanin value of 104-20800 $\mathrm{mg} /$ day is obtained. From the analysis of anthocyanin content, the product is $60.40 \mathrm{mg} \mathrm{/} \mathrm{L}$, so that the content of anthocyanin content is $6.04 \mathrm{mg}$. the two serving sizes of Dragon Yam Bean Velva have fulfilled the minimum anthocyanin needs of $58 \%$ of daily distilled food so that the two serving sizes of Dragon Yam Bean Velva have covered anthocyanin needs by $81 \%$ minimum requirement.

Based on the results of anthocyanin level calculations in formula 2 using the literature of $6.8 \mathrm{mg}$, it shows that anthocyanin levels are not much different from the results of the analysis test, a small difference can be caused by the fruit varieties used.

When compared with anthocyanin levels in $100 \mathrm{~g}$ of red dragon fruit, the content of anthocyanin in red dragon fruit is more than $8.8 \mathrm{mg}$ which makes red dragon fruit have higher anthocyanin levels compared to Velva. It can be caused because in 100 $\mathrm{g}$, Velva does not only consist of dragon 
fruit, but there are other contributing ingredients such as bengkuang and other raw materials.

\section{Dragon Bengkuang Velva Inulin Fiber Levels}

Based on the results of the count, Inulin in the product per serving size obtained as much as $2.1 \mathrm{~g} /$ serving size. Based on BPOM regulations, daily consumption of dietary fiber including Inulin is at least $3 \mathrm{~g} /$ daily portion.

The requirement for nutrients that can be supplied from distilled foods is $10 \%$, so that the inulin needs of distilled food is at least $0.3 \mathrm{~g} /$ serving size. While Dragon Yam Bean Velva products have $2.1 \mathrm{~g}$ of inulin content. Per serving of Dragon Yam Bean Velva, products can meet Inulin needs by $700 \%$ of the minimum requirement. One serving of Dragon Yam bean Velva, which contains $2.1 \mathrm{~g}$ of Inulin

meet the minimum inulin requirement, comes from snack foods as much as $350 \%$.

When compared with the inulin fiber content in $100 \mathrm{~g}$ of jicama fruit, the content

The inulin fiber in yam is $6.5 \mathrm{mg}$, which is higher than that of Velva. It is because $100 \mathrm{~g}$ of velva does not only consist of yam but other ingredients contribute such as dragon fruit and other raw materials.

According to Oliviera (2009), in Artanti states that intake of Inulin is proven to influence probiotic activity significantly. Prebiotics are living microorganisms that are consumed in sufficient quantities so that they can provide health benefits to the host. ${ }^{54}$

The positive effects of the probiotic activity are divided into three aspects, namely nutrition, physiology, and antimicrobial. The nutritional aspect comes from the availability of enzymes that help the metabolism absorption of lactose (lactase). Probiotic activity helps synthesize vitamin $\mathrm{K}$, folic acid, pyridoxine, pantothenic acid, biotin and riboflavin. It can remove toxins from the components of food metabolites in the intestine. Physiological aspects include the ability to maintain a balanced microbial composition of the intestine to reduce the risk of infectious diseases and stimulate the body's immunity [54]. The aspect of antimicrobial ability is expressed through the ability to improve resistance to pathogens. But the activity of this pathogen can also originate from the adhesion ability of probiotics. ${ }^{54}$

\section{CONCLUSION}

Formula 2 with a balance of $30 \%$ bengkuang: $70 \%$ dragon fruit is the chosen formula that can meet the needs of anthocyanin from intermittent foods by $81 \%$ by consuming 2 serving sizes and minimum inulin requirements from distilled food by $350 \%$ by consuming one serving size. Based on the hedonic test results obtained formula 2 as the formula with the highest level of preference, this is because formula 2 has a percentage of likes and likes the color aspect as much as $90 \%, 86.6 \%$ flavor, $70 \%$ aroma, and $93.4 \%$ texture. The level of anthocyanin in one serving is $6.04 \mathrm{mg}$, while the level of serving Inulin is $2.1 \mathrm{~g}$. It is recommended that research should be carried out on the amount of stabilizer (CMC) for the type of raw material used so that Velva texture with optimal quality is obtained. This product does not meet the needs of anthocyanin based on the recommendation of anthocyanin from distilled food so that it is necessary to substitute other food ingredients that contain high anthocyanin such as tape black sticky rice.

\section{REFERENCE}

1. Maryani Herti, Handajani Adianti, Roosihermiatie, Handajani Adianti. Faktor-faktor yang berhubungan dengan Pola kematian pada Penyakt Degeneratif di Indonesia. Pusat Penelitian dan Pengembangan Sistem dan Kebijakan Kesehatan. Surabaya. 2010. 1(13). $42-43$.

2. Yani M. Mengendalikan Kolesterol Pada Hiperkolesterolemia. Jurnal Olahraga Prestasi. 2015;11(2):1-7.

3. Kementerian Kesehatan Republik Indonesia. 2013. Riset Kesehatan Dasar 
(RISKESDAS) 2013. Jakarta: Badan Penelitian dan Pengembangan Kesehatan.

4. Pakar Gizi Indonesia. 2016. ILMU GIZI: TEORI DAN APLIKASI. Jakarta: Penerbit Buku Kedokteran EGC.

5. Fairudz A, Nisa K. Pengaruh Serat Pangan Terhadap Kolesterol Penderita Overweight. Fakultas Kedokteran Universitas Lampung. 2015:4(8);123125

6. Sigarlaki, Edgar D. 2016. Pengaruh Pemberian Buah Naga Merah (Hylocereus polyrhizus) Terhadap kadar Kolesterol Total. Fakultas Kedokteran. Universitas Lampung. 2016;5(5):14-15

7. Harmayanti, E. 2011. Potensi serat bengkuang (sebagai prebiotic pada Bifidobacterium lognum dan Lactobacillus A. Seminar nasional PATPI.

8. Wimala, Marizka. 2014 Penetapan Kadar Inulin Dalam Air Umbi Bengkuang (Pachyrhizus erosus L ) Dari Beberapa Daerah Di Jawa Timur Berdasarkan Perbedaan Ketinggian Dengan Metode KLT Densitometri. Skripsi. Fakultas Farmasi. Universitas Jember. Jember.Kamisna. Pengaruh Konsentrasi Sari Buah dan Jenis Gula Terhadap Mutu Minuman Fungsional Dari Bengkuang. Jurnal Litbang Industri. 2014:4(1);19-27

9. Choo WS, Yong WK. Antioxidant properties of two species of Hylocereus $\mathrm{s}$ fruits. Pelagia Res Libr. 2011;2(3):418-25.

10. Maria D N, Zubaidah E. Pembuatan Velva Jambu Biji merah Probiotik (Lctobacillus acidophilus) Kajian Penambahan Sukrosa dan CMC. Jurnal Pangan dan Agroindustri.2014;2(4):1828

11. Indriasari I. Ekstrak ethanol buah naga merah (hylocereus polyrhizus) memperbaiki profil lipid pada tikus wistar jantan (rattus norvegicus) dyslipidemia. Skripsi. Denpasar: Universitas Udayana; 2012

12. Hardisman. Pencegahan Penyakit Degeneratif dan Pengaturan Makan dalam Kajian Kedokteran dan AlQuran. Fakultas Kedokteran Universitas Andalas. Padang. 2010. 1(34). 40-46.
13. Trisnowati, Heni. Pemberdayaan Masyarakat untuk Pencegahan Faktor Risiko Penyakit Tidak Menular (Studi pada Pedesaan Di Yogyakarta). Jurnal MKMI. 2018. 1(14). 18-19.

14. Kementrian Kesehatan Republik Indonesia, 2013. Diabetes Melitus Penyebab Kematian Nomor 6 di Dunia: Kemenkes Tawarkan Solusi CERDIK Melalui Posbindu. http://www.depkes.go.id/index.php?vw $=2 \& \mathrm{id}=2383$. Tanggal akses: 26/12/2018

15. Maryani H, Handajani A, Roosihermiatie B. Faktor-Faktor Yang Berhubungan Dengan Pola Kematian Pada Penyakit Degeneratif di Indonesia. Buletin Penelitian Sistem Kesehatan. 2010. 1(13). 42-43

16. Estiasih Teti, Saputro Prasetyo Sonny. Pengaruh Polisakarida Larut Air (PLA) dan Serat Pangan Umbi-Umbian Terhadap Glukosa Darah: Kajian Pustaka. Jurnal Pangan dan Agroindustri. 2015. 2(3). 758 - 759.

17. Mansjoer, Arif. 2000. Kapita Selekta Kedokteran, Edisi 3 Jilid 2. Jakarta: media Aesculapius

18. Raymond, J.L., Couch, S. C., 2017. Nutrition in Weight Management. Dalam Mahan, L. K., Raymond, J. L. 2017. Krause's Food \& The Nutrition Care Process. Fourteenth edition. Missouri: Elsevier. Hal 647 - 650

19. Drechsler et al. HyperlipidemiaTriggered Neutrophilia Promote Early Atherosclerosis. Journal of American Heart Association. 2010 [cited 17 june 2018]. Available from: http//circ.ahajournals.org/122/18/1837

20. Pakar Gizi Indonesia. 2016. ILMU GIZI: TEORI DAN APLIKASI. Jakarta: Penerbit Buku Kedokteran EGC.

21. Kelly E. B., 2006. Obesity Health and Medicine Issues Today. London: Greenwood Press.

22. Barasi M. E. 2009. At a Glance ILMU GIZI. Diterjemahkan oleh: Hermin Halim, S.Si, M.Nutr.Diet., Apt. Jakarta: Penerbit Erlangga.

23. Budiyanto A. K. 2009. Dasar Dasar Ilmu Gizi. Malang: UMM Press.

24. Andiani M, Wirjatmadi B. 2012. Pengantar Gizi Masyarakat. Jakarta: Kencana. 
25. Wallace T.C., Giusti M.M. Anthocyanins. Adv Nutr 2015;6:620622.

26. Fernando, J. M. R. C, Senadeera, G. K. R., 2008. Natural anthocyanins as photosensitizer for dye-sensitized solar device.

Current Science.2018:95(5);663-666

27. Priska M, Peni N, Carvallo L, Ngapa Y. Review : Antosianin dan pemanfaatannya. Indonesian E-Journal of Applied Chemistry. 2018.2(6). 8485.

28. Werdhasari, Asri. Peran Antioksidan Bagi Kesehatan. Jurnal Biotek Medisiana Indonesia. 2014 :3(2); 59-68.

29. Tsuda, Takanori. 2012. Review Anthocyanis as Functional Food Factors. Chubu University

30. Lestari P I. 2013. Pengembangan Validitas Metode KLT Densitometri Untuk Penerapan Kadar Inulin Dalam Ekstrak Air Umbi Bengkuang. Skripsi. Fakultas Farmasi. Universitas Jember. Jember

31. Prior. Whole Berries versus Berry Anthocyanins: Interaction with Dietary Fat Levels in the C57BL/6J Mouse Model of Obesity. J. Agric. Food Chem. 2008:56(3)

32. Lucioli, Simona. Anthocyanins: Mechanism of Action and Therapeutic Efficacy. Italy. Dalam Medicinal Plants as Antioxidant Agents: Understanding Their Mechanism of Action and Therapeutic Efficacy, 2012: 27-57 ISBN: 978-81-308-0509-2 Editor: Anna Capasso

33. Zamora-Ros. Estimation Of The Intake Of Anthocyanidins And Their Food Sources In The European Prospective Investigation Into Cancer And Nutrition (EPIC) Study. British Journal of Nutrition.2011:106(7);1090-1099.

34. Satyatama, Dian Indrayani. 2008. Pengaruh Kopigmentasi Terhadap Stabilitas Warna Antosianin Buah Duwet (Syzygium cumini). Tesis. Program Studi Ilmu Pangan Institut Pertanian Bogor.

35. Qin Y, Xia M, Ma J, Hao Y, Liu J, Mou H. Anthocyanin supplementation improves serum ldl- and hdl-cholesterol concentrations associated with the inhibition of cholesteryl ester transfer protein in dyslipidemic subjects. Am J Clin Nutr. 2009;90(4);85-92.
36. Setiarto R, Widhyastuti N, Saskiawan I, Safitri R. Pengaruh Variasi Konsentrasi Inulin Pada Proses Fermentasi Oleh Lactobacillus acidophilus, Lactobacillus bulgaricus, dan Streptococus thermophilus. Bioporal Insustri.2017:8(1);1-17

37. Sapriyanti R, Nurhartadi E, Ishartani D. Karakteristik Fisikokimia dan Sensori Velva Tomat (Lycopersium esculentum Mill) dengan Pemanis Madu. Jurnal Teknologi Hasil Pertanian, 2014:7(1)

38. Basito Bara Yudhistira, Meriza Dara Audina. Kajian Penggunaan Bahan Penstabil CMC (Carboxyl Methyl Cellulosa) dan Karagenan dalam Pembuatan Velva Buah Naga Super Merah. Jurnal Teknologi dan Industri Pertanian Indonesia. 2018. 1(10). 43 46.

39. Kusbiantoro B, H Herawati, A. B. Ahza. Pengaruh Jenis Konsentrasi bahan Penstabil terhadap Mutu Produk Velva Labu Jepang. Journal Hort. 2005. 3(15). 224-227.

40. Choo WS, Yong WK. Antioxidant properties of two species of hylocereu s fruits. Pelagia Res Libr. 2011;2(3):41825.

41. Taiwan Food Industry Development and Research Authorities Report Code 85-2537 dalam Panjuantiningrum (2009)

42. Reimer RA, Grover GJ, Koetzner L, Gahler RJ, Lyon MR, Wood S. The Soluble Fiber Complex PolyGlycopleX Lowers Serum Triglycerides and Reduces Hepatic Steatosis in Highsucrose-fed Rats. Faculty of Kinesiology and Department of Biochemistry \& Molecular Biology, University of Calgary, Calgary, Alberta, Canada T2N 1N4, Department of Physiology and Biophysics, Robert Wood Johnson Medical School, Piscataway, NJ 08854, USA. Nutrition Research 31 (2011) 296-301

43. Hermianti W, Diza Y, Firdausni, Wahyuningsih T. Pengaruh Penggunaan Kadar Air dan Penggunaan Bahan Pengikat Kadar Air Dalam Pembuatan Cake Bengkuang. Jurnal Litbang Industri.2016:6(2);117-125

44. USDA. 2016. Basic Report 09316, Srtawberries, raw. National Nutrient Database for Standard Reference.

45. Tekpang Unimus. 2006. Pengujian Organoleptik (Evaluasi Sensori) dalam 
Industri Pangan dikutip dari tekpan.unimus.ac.id pada tanggal 25 Agustus 2018

46. Sinaga A, Luliana S, Fahrurroji A. Losio Antioksidan Buah Naga Merah (Hylocereus polyrhizus Britton and Rose). Program Studi Farmasi Fakultas Kedokteran. Universitas Tanjungpura. 2015. 1(2).12-13

47. Sampebarra A. Karakteristik Warna Antosianin dari Biji Kakao Non Fermentasi Sebagai Sumber Zat Warna Alam. Jurnal Industri Hasil Perkebunan. 2018. 1(13). 63-64

48. Sari T, Siagian A, Aritonang E. Kandungan Gizi Roti Tawar Bengkuang. Fakultas Kesehatan Masyarakat. Universitas Sumatera Utara. 2015.

49. Fajarwati N, Parnanto N, Manuhara G. Pengaruh Konsentrasi Asam Sitrat dan Suhu Pengeringan Terhadap Karakteristik Fisik, Kimia, dan Sensori Manisan Kering Labu Siam dengan Pemanfaatan Pewarna Alami dari Ekstrak Rosela. Jurnal Teknologi Hasil Pertanian. 2017. 1(9). 62-63.

50. Rahmawati P. Penambahan Konsentrasi Bahan Penstabil dan Konsentrasi Sukrosa Terhadap Karakteristik Sorbet Murbei Hitam [Skripsi]. Universitas Pasundan Bandung. 2017

51. Sapriyanti $R$, Nurhartadi E, Ishartani D. Karakteristik Fisikokimia dan Sensori Velva Tomat (Lycopersicum esculentum Mill) dengan Pemanis Madu. Jurnal Teknologi hasil Pertanian. 2014. 1(7). 60-61

52. Sabuluntika N. Kadar $\beta$-Kaaroten, Antosianin, Isoflavon, dan Aktivitas Antioksidan pada Snack Bar Ubi Jalar Kedelai Hitam Sebagai Alternatif Makanan Selingan Penderita Diabetes Melitus Tipe 2 [Skripsi]. Universitas Diponogoro. 2013

53. Artanti A. Pengaruh Prebiotik Inulin Fruktooligosakarida (FOS) terhadap Pertumbuhan Tiga Jenis Prebiotik [Skripsi]. Institut Pertanian Bogor. 2009

54. Purtra A S, Meta I W, Sundari C D. Analisis Total Fenol pada Berbagai Rebusan Kulit Salak Bali Sibetan Karang Asem Sebagai Minuman Fungsional. Meditory. 2016. 2(4). 7273
55. Tunikasari A S, Suhanantyo, Dharmawan R. Pengaruh Ekstrak Bengkuang (Pachyrhizus erosus) terhadap Kadar Total Darah Tikus Putih (Rattus norvegicus) yang Diberi Diet Tinggi Lemak [Skripsi]. Universitas Sebelas Maret. 2011

56. Suharti N, Suarmin O, Djamaan A. Kaakteristik Pati Umbi Bengkoang (Pachyrizus erosus (L.)Urban) [Skripsi]. Fakultas Farmasi Universitas Andalas. 2011

57. Lestari A C. Pengaruh Konsentrasi Penstabil dan Gula Stevia Terhadap Karakteristik Minuman Fungsional Kulit Buah Naga Merah [Skripsi]. Universitas Pasundan. 2018

58. Kesuma T I. Pengaruh Jenis dan Konsentrasi padaTerhadap Karakteristik Tepung Nanas (Ananas comocus (L) Merr) dan Pengaruh CMC Terhadap Karakteristik Velva Berbahan Dasar Tepung Nanas. [Skripsi]. Institut Pertanian Bogor. 2011

59. Sumarni, Muzakir, Tamrin. Pengaruh Penambahan CMC (Carboxyl Methyl Cellulose) Terhadap Karakteristik Organoleptik, Nilai Gizi, dan Sifat Fisik Susu Ketapang. Jurnal Sains dan Teknologi Pangan. 2017. 3(2). 609-612.

60. Fauziyah, Roro Nur, Putri, Mardiyah Maulida, Surmita. 2020. Effect of Pie Based on Fermented Black Glutinous Rice and Sweet Purple Potato to Frequency of Defecation in Adolescents with Contipation. International Medical Journal. Vol 25, Issue 04. Artikel https://www.seronijihou.com/volume/I MJ/25/4/effect-of-pie-based-onfermented-black-glutinous-rice-andsweet-purple-potato-to-frequency-ofdefecation-in-adolescents-withconstipation-5ec80c6fdc2fa.pdf

61. Trinovani, Elvi, Afifah Riska Rafa, Fauziyah, Roro Nur. 2020. Determination of Antosianin Total Levels and Antioksidant Activities in Black Glutinous Rice Extract and Fermented Black Glutinous Extract. International Medical Journal. Vol 25, Issue $05 . \quad$ Artikel https://www.seronijihou.com/volume/I $\mathrm{MJ} / 25 / 5 /$ determination-of-antosianintotal-levels-and-antioxidant-activitiesin-black-glutinous-rice-extract-andfermented-black-glutinous-rice-extract5ec8099a8eb18.pdf 
62. Kusmiyati, Mimin, Trinovani, Elvi, Fauziyah, Roro Nur. 2020. Activity of Mixed Ethanol Extract Selected Black Tea (Camelia sinesis L.) and Stevia (Stevia rebaudiana B.) as an Alternative Anti Diabetes Herbal Medicine. International Medical Journal. Vol 25, Issue $06 . \quad$ Artikel https://www.seronijihou.com/volume/I MJ/25/6/activity-of-mixed-ethanolextract-selected-black-tea-cameliasinensis-l-and-stevia-steviarebaudiana-b-as-an-alternative-anti- diabetes-herbal-medicine5ef522fdaa75e.pdf

63. Fauziyah, Roro Nur, Mimin AMinah, Osman Syarief, Holil M Par'I, Widi Hastuti, Surmita. 2020. Effectiveness of Steamed Brownies Base on Fermented Black Glutinous Rice on Decreased Waist Circumference in Abdominal Obesity. Jurnal Ilmu dan Teknologi Kesehatan. Vol x No x. Artikel http://ejurnal.poltekkesjakarta3.ac.id/in dex.php/jitek 